\title{
Distinction between inflection and derivation of learning reduplication in Mandarin
}

\author{
Shi Yuxin ${ }^{1}$, I Dewa Putu Wijana ${ }^{2}$, Y. Tri Mastoyo ${ }^{3}$, Hermina Sutami ${ }^{4}$ \\ 1,2,3 Department of Linguistics, Universitas Gadjah Mada, Indonesia \\ ${ }^{4}$ Department of Linguistics, Univeritas Indonesia, Indonesia
}

\section{Article Info \\ Article history: \\ Received Sept 13, 2019 \\ Revised Oct 23, 2019 \\ Accepted Oct 30, 2019}

\section{Keywords:}

Form

Mandarin

Reduplication

Word class

\begin{abstract}
Reduplication as a word-formation process in Mandarin, which is one of the most difficult knowledge to comprehend for scholar and student. Theoretically this research offers an approach that is different from what has been made by previous researchers. Using the M.D.S Simatupang free context approach this research contrasts the reduplicative forms of all word classes and shows the relationships between them (AA, AABB, $\mathrm{ABAB}, \mathrm{ABB})$ and their basic forms $(\mathrm{A}, \mathrm{AB})$, then based on test of categorical word and test of lexical decomposition as proposed by J.W.M Verhaar, this study analyzes and explains reduplication and inflectional reduplication in Mandarin in order to students understand as their meaning vocabularies. As a result, this research examines the derivational and inflectional reduplication in Mandarin all at once can disseminate the use of morphological theory. In addition, this study discusses Mandarin reduplication based on various word classes that are contained as a basis for the relevant form of reduplication. Beginner research results will be presented in this study in order to stimulate more complete writing, it will be better if this research can be disseminated in order to add learning and reading material for future research.
\end{abstract}

Copyright $\odot 2019$ Institute of Advanced Engineering and Science. All rights reserved.

\section{Corresponding Author:}

SHI YUXIN

Department of Linguistics, Universitas Gadjah Mada,

Bulaksumur, Caturtunggal, Depok, Sleman, Daerah Istimewa Yogyakarta 55281. Indonesia

Email: shi.yuxin.0214@gmail.com

\section{INTRODUCTION}

Mandarin is spoken around Beijing and forms the basis of the country's national language [1]. Reduplication is one of the most productive word formation phenomena in Mandarin, as we will see throughout this research. Reduplication in Mandarin is a creative phenomenon, virtually affecting all major lexical categories (nouns, verbs, adjectives). This research will investigate reduplication of Mandarin with specific attention to its part in derivational morphology.

Typologically, Rubino lists two types of reduplication are distinguished based on the size of the Chinese reduplicant: full reduplication and partial reduplication [2]. Full reduplication involves a reduplication of the entire word. Full word lexical reduplication: 年nián 'year' $>$ 年年nián nián 'every year'. Reduplicated monosyllabic nouns like 年年nián nián are abbreviated as AA form. Partial reduplication involves a reduplication of only part of the word. For example, 暗沉àn chén 'dark' > 暗沉沉àn chén chén 'very dark'. Reduplicated monosyllabic nouns like 暗沉沉àn chén chén are abbreviated as AAB form.

According to Chiara \& Bianca, reduplication in Mandarin syllables are usually facilitated as symbols A and symbol B, symbol A is used for the first syllable in reduplication, symbol ' $\mathrm{B}$ ' is used to express the second syllable consisting of two syllables. Both monosyllabic $(\mathrm{A} \rightarrow \mathrm{AA})$ and disyllabic $(\mathrm{AB} \rightarrow$ 
ABAB) bases can reduplicate [3]. Research on reduplication form (except semantic reduplication forms) in Mandarin is determined by scholars: AA form, AAB form, AABB form, and ABAB form. Based on the data examined, forms relate to reduplication in Mandarin are AA form, AAB form and AABB form [4]. E.g.

a. AA form: 天 $t i \bar{a} n$ 'day'> 天天tiān tiān 'everyday';

星xīng 'star' > 星星xīng xīng 'stars'.

b. ABB form: 暗沉àn chén 'dark'> 暗沉沉àn chén chén 'darker/very dark';

c. AABB form: 坑洼kēng $w \bar{a}$ 'hole' > 坑坑洼洼kēng kēng $w \bar{a} w \bar{a}$ 'holes/a lot of holes';

上下shàng xià 'top and bottom' > 上上下下shàng shàng xià xià 'from top to bottom'.

d. $\mathrm{ABAB}$ form: 火红 huǒ hóng 'vermilion' > 火红火红 huǒ hóng huǒ hóng 'more vermilion /very vermilion'.

In the morphology we find a number of criteria for distinguishing between inflection and derivation $[5,6]$. A first criterion is that derivation may change syntactic category, unlike inflection. A second criterion is that, unlike derivation, inflection is obligatory. A potential problem for this criterion is that it is theorydependent in its application. A third distinguishing characteristic of inflection is full productivity. Examples of inflected words bases are see in Table 1.

Table 1. Some type of inflection

\begin{tabular}{ccc}
\hline Type of inflection & Input & Output \\
\hline Passive & do & (be) done \\
Comparatives & big & bigger \\
Plural nouns & book & books \\
\hline
\end{tabular}

From cases above, some problems are caused by the reduplication process. In the case (3) above, basic word 上下shàng xià and 坑洼 kēng wā are both nominal domain, and equally duplicated with the AABB form, the reduplicative meanings which are resulted from these two words are totally different. As for disyllabic reduplicated nouns坑坑洼洼kēng kēng wā $w \bar{a}$, the disyllabicity of the base 坑洼 kēng $w \bar{a}$ point to uncontroversially nominal bases. But category 上下shàng xià is changed by AABB form. Reduplication of 上下shàng xià 'top and bottom' is上上下下shàng shàng xià xià 'from top to bottom', which manifests property of lexeme formation and, formally, approaches derivational phenomena of reduplication.

And then, in the cases (1) and (3) above, 星xīng 'star' > 星星xīng xīng 'stars' and 坑洼kēng wā 'hole'> 坑坑洼洼kēng kēng wā wā 'holes', no research ever showed whether this plurle noun is a lexical meaning like 'a lot of' which is created by reduplication or an inflectional plural noun like suffix '-s' in English which is presented by AA or AABB form in Mandarin. Meanwhile, adjective reduplications in (2) and (4) above seems comparative degree forms which is presented by ABB or AABB.

As far as Mandarin is concerned, reduplicative nouns may be a plural form, and many adjective meanings look like comparative degree forms. These criteris show that inflection may be ture for reduplicaton in Mandarin. There are so many meanings and formations that make learning reduplication in Mandarin more confused. And distinctions between inflection and derivation are difficult to understand reduplication in Mandarin. The purpose of this research is to picture all reduplication formation and meaning in Mandarin based on the distinction between derivation and inflection.

\section{RESEARCH METHOD}

This research investigates the derivational reduplication in Mandarin without context, i.e. free context [7]. The derivation sometimes changes the categorical base word. Therefore, it's necessary to check if the reduplication is derivational and inflectional. Two tests will be used as proposed by Verhaar [8] in free context: (1) test of categorical word; (2) test of lexical decomposition;

Test (1) can be used to determine whether reduplication is derivational or paradigmatic/inflectional, using observational techniques to observe the property of the relevant base word. Derivation typically forms new reduplication and can be category or lexical meaning changing. As shown by the case: 天tiān 'day' > 天 天tiān tiān 'everyday', where nominal base has been changed to adverbial. As Verhaar's (1) test of categorical word said, derivation typically forms new lexeme can change category of base.

If reduplication doesn't make a change in the categorical base word, the resulting categorical reduplication is the same as the categorical base word base word, if test (1) can't determine, and test (2) will be used. And if duplicated word dose not display changing property, which means that is inflectional reduplication. 


\section{RESULTS AND ANALYSIS}

Monosyllabic bases can reduplicate as A > AA. A lot of words can reduplicate with AA form in Mandarin, delivering an entire increasing function, verbal reduplications appear to be creative: A $y \bar{\imath} \mathrm{A}, \mathrm{A} l e \mathrm{~A}$ and A le yì A.

\subsection{AA Form}

\subsubsection{Meaning of 'Every or each': Noun Quantifier + AA Form}

AA form are productive with nominal bases [9]. However, whether or not the AA form seems to depend on the meaning and the semantic feature of the bases. Only nominal bases that have a noun quantifier (noun has quantificational meaning) can contain AA form with the meaning 'every or each' [10].

a. 年nián 'year' > 年年nián nián 'every year';

b. 家 $j i \bar{a}$ 'family' > 家家 $j i \bar{a} j i \bar{a}$ 'every family';

c. 天tiān 'day'> 天天tiān tiān 'every day';

d. 月уиѐ 'month'> 月月уиѐ уиѐ 'every month';

e. 岁suì 'year (old)'> 岁岁suì suì 'every year'.

As shown by the cases above (a) -- (e), where each of reduplication contains the quantifier 每 měi 'every or each'. Reduplication of monosyllabic nouns proper expresses a 'every or each' meaning, which manifests property of lexeme, and some of categorical bases have been changed. As Verhaar's test of lexical decomposition said, derivation typically forms new lexeme can change lexical meaning of bases. So, reduplicative process noun quantifier + AA form is a derivational process.

\subsection{2. 'Inflectional Plural Noun': Nominal Lexeme + AA Form}

Reduplication is attested with a variety of meanings; this phenomenon is associated with its prototypical function of intensification. In the nominal, reduplication gives as a result plural noun, this may show one of the reduplicative values in Mandarin:
a. 星xīng 'star' > 星星xīng xīng 'stars';
b. 框 kuāng 'frame’>框框 kuāng kuāng 'frames';
c. 杠 gàng 'line' > 杠杠gàng gàng 'lines'.

The data above show that duplicated noun dose not display changing property, reduplication星星 xīng xīng 'stars' and relevant base星xing 'star'has the same category status. In certain contexts, such as几颗 星星 jǔ ke xìng xīng 'many stars', reduplication is obligatory cause *几颗星 or 几颗杠 will never be used in natural speech. So, reduplication like 星星xīng xīng should be an inflectional plural noun.

\subsection{3. 'Try' and 'Iterative': Verbal Lexeme + AA Forms}

Generally, verbs can be applied with AA forms in Mandarin. According to Wáng wěijìng, verbal lexemes that have the potential to experience reduplication are action verbs [11]. Thus, existential verbs, relational verbs, non-voluntary verbs, directional verbs and capital verbs have no potential for reduplication, either in the form of AA forms or other forms. For example:

a. relational verbs:

认为 'considers' $>$ * 认为认为, 是 'is' $>$ * 是 是;

b. non-voluntary verbs:

开始 'start’> * 开始开始, 死 ‘die’>*死死;

c. capital verbs:

能 ‘can’>* 能 能, 可以 ‘can’>* 可以可以;

d. existential verbs:

在 ‘exists'> * 在 在, 有 'have/has'>* 有 有;

The meaning that can be related to the reduplication of AA forms like 看看 kàn kàn is 'iterative' and 'brief'. The following example might clarify verbs that have the potential to reduplicate the AA form.

a. 看 kàn 'look'> 看看 kàn kan 'have a look (for a while)';

b. 写 xiě 'write’> 写写 xiě xiě 'write for a while';

c. 逛 guàng 'walk'> 逛逛 guàng guàng 'take a short walk';

d. 试 shì 'try'> 试试 shì shì 'try briefly';

e. 想 xiăng 'think’> 想想 xiăng xiăng 'have a think briefly'.

Based free-context reduplication on examples (a) - (e), it can be seen immediately and clearly that the reduplication process of the AA form of verb base words does not change the word class, for example example (b) both 写 xiě 'write' and 写写 xiě xiě 'write for a while' are both in the category of verbs. 
However, the process changes the lexical meaning. Based on the lexical decomposition test, this reduplication process can be considered derivational reduplication. Because reduplication of AA forms in Mandarin does not recognize verb affixation, verb morphemic reduplication does not function to change word classes. That change is the lexical meaning which is associated with [+ iterative] and [+ briefly]. So, this reduplication process is classified as derivational reduplication.

\subsection{4. 'Very' and 'Intensive': Adjective Lexeme + AA Form}

AA form is that not all adjectives can be duplicated in natural speech. Adjective generally relate to situation or condition, color, size, distance, nature of people / animals, sensing, and feeling [12]. To give the meaning of 'very' and highlight the conditions and conditions involved, for example 红 hóng 'red'> 红红 hóng hóng 'very red' while the red color is highlighted. Mandarin often uses AA forms related to these adjectives. This will be shown in the following example (a) - (e).

a. 红 hóng 'red'> 红红 hóng hóng 'very red';

b. 黄 huáng 'yellow’> 黄黄 huáng huáng 'very yellow';

c. 深 shēn 'in'> 深深 shēn shēn 'very deep';

d. 长 cháng 'long'> 长长 cháng cháng 'very long';

e. 冷 lěng 'cold'> 冷冷 lěng lěng 'very cold'.

Examples (a) - (e) show that the reduplication of adjective AA forms does not change word groups either. Because both 红 hóng 'red' and 红红 hóng hóng 'very red' are both categorized as adjectives in Mandarin, the word categorical membership test cannot determine the reduplication process so the lexical decomposition test will be used.

As in example (d), semantic feature [+intensive] is created in长长 cháng cháng by reduplication, whereas this process shows the meaning 'very'. Thus, reduplication of the AA form of basic categories of adjectives in Mandarin does not have grammatical functions, but functions lexically. The lexical function of the AA form reduplication has a semantic feature, that is [+ intensive] and is related to the meaning 'very'. Meanwhile, the meaning of 'very' does not function to form comparative sentences in Mandarin [13]. Reduplication process has changed lexical meaning. So, the reduplication process is classified as derivational reduplication.

\subsection{5. 'Very' and 'Intensive': Adverbial Lexeme + AA Forms}

AA form are productive with adverbial lexemes. The meaning of 'very' and 'intensive' is contained by the reduplication [14]. Adverbs that have the potential to be duplicated with the formulation A> AA are examples (a) - (e) below.

a. 速 sù 'quickly'> 速速 sù sù 'hastily';

b. 渐 jiàn 'gradually'> 渐渐 jiàn jiàn 'very slowly';

c. 频 pín 'some times'> 频频 pín pín 'many times';

d. 常 cháng 'often'> 常常 cháng cháng 'frequently';

e. 屡 $l \check{u}$ 'over'> 屡屡 $l \check{u} l \check{u}$ 'over and over'.

As shown by the cases above (a) -- (e), There is also no categorical change in the word because both the basic morpheme and the reduplicative form are both categorized as adverbs. However, each of reduplication contains semantic feature 'intensive'. Going back to research topic, reduplication of monosyllabic adverbs proper expresses 'intensive' and 'very' meaning, which manifests property of lexeme. As Verhaar's test of lexical decomposition said, derivation typically forms new lexeme can change lexical meaning of bases. Based on this test, it can be said that the change in lexical meaning is caused by derivational reduplication. Reduplicative process adverbial lexeme + AA form is a derivational process.

\subsection{6. 'A by A': Numeral Lexeme + Form AA}

The basic numeral words that can potentially be duplicated with the formulation are:

a. $\quad-y \bar{\imath}$ 'one'> - $y \bar{l} y \bar{\imath}$ 'one by one';

b. 两 liǎng 'two'> 两 两 liǎng liăng 'two by two';

c. 万 wàn 'ten million'> 万万 wàn wàn 'sure'.

The basic numeral words are duplicated with the AA form, then the distributive meaning ' $\mathrm{A}$ by A' is produced. Except for example (c) the reduplication process results in figurative meaning. 


\subsection{AABB Form}

As we dub it in the chapter, the AABB form, which is compared with lexeme $\mathrm{AB}$.

\subsection{1. 'Distributive' on AABB Form: Nominal Lexeme + AABB Form}

Disyllabic bases can reduplicate as $\mathrm{AB}>\mathrm{AABB}$. As we have seen, reduplicated monosyllabic nouns have 'every/each' or 'plural' meaning. In fact, Disyllabic nouns have 'plural' meaning too, and 'every/each' meaning more varied at $\mathrm{AABB}$ form. Reduplicated monosyllabic nouns are known as have a distributive meaning $[10,15,16]$.

a. 年岁nián suì 'year'> 年年岁岁nián nián suì suì 'every year';

b. 分秒fēn miăo 'minute' > 分分秒秒fên fēn miăo miăo 'every minute';

c. 村寨 cūn zhài 'village'> 村村寨寨 cūn cūn zhài zhài 'every village';

d. 里外 ľ̀ wài 'inside outside' >里里外外 lǐ lǐ wài wài 'from inside to outside';

e. 上下shàng xià 'top bottom'>上上下下shàng shàng xià xià 'from top to bottom';

f. 风雨 fēng yǔ 'problem (metaphor)' > 风雨雨 fēng fēng yǔ yǔ 'a lot of problem';

g. 瓶罐píng guàn 'bottle' > 瓶瓶罐罐píng píng guàn guàn 'a lot of bottle';

h. 坑洼kēng $w \bar{a}$ 'hole'> 坑坑洼洼kēng kēng $w \bar{a} w \bar{a}$ 'a lot of hole'.

As we have seen in above cases, some very flexible lexical items seem to indicate distributive meaning. These reduplications can function either as an argument or as an adverbial. As we have seen reduplications in example (1), (2) and (3) contain the quantifier 每 měi 'every or each'. Meanwhile, in example (4) and (5) locality noun as base, category of relevant reduplication will change to adverbial. Going back to research topic, lexical meaning or categorical basis have been changed by reduplicative process in cases (1) --(5).

\subsection{2. 'plural meaning' on AABB Form}

As shown in (6) --(8), above show that duplicated noun dose not display changing categorical basis, reduplication坑坑洼洼kēng kēng $w \bar{a} w \bar{a}$ and relevant base坑洼kēng $w \bar{a}$ has the same category status.

A 'plural-collective meaning' [17] means reduplicative processes noun + AABB form may has an inflectional marking. Reduplicative process noun + AABB form is a derivational process. As criterion, unlike derivation, inflection is obligatory [18]. 几个坑洼 ǰ̌ gè kēng $w \bar{a}$ 'many holes' is acceptable in a plural context, reduplication $\mathrm{AABB}$ is not obligatory (*many hole, inflectional marking suffix -s in a plural context is obligatory for countable noun). So, it can be said that reduplication AABB process just change lexical meaning which is caused by derivational reduplication. Reduplicative process nominal lexeme + AABB form is a derivational process.

\subsection{3. 'Very' and 'Intensive': Adjective Lexeme + AABB Form}

According to Shi Qin, AABB reduplication patterns are consisted of two patterns as the form of reduplication, such as repeating Mandarin adjective干净 gān jìng into another adjective干干净净 gān gān jìng jìng [19]. Adjective generally relate to situation or condition, color, size, distance, nature of people / animals, sensing, and feeling. To give the meaning of 'very' and highlight the conditions and conditions involved, for example 正当 zhèng dāng 'right'> 正正当当 zhèng zhèng dàng dàng 'pretty right' while the 'correct' is intensified. This will be shown in the following example (a) -- (e).

a. 正当 zhèng dāng 'right'> 正正当当 zhèng zhèng dàng dàng 'pretty right';

b. 清楚 qīng chǔ 'clear’> 清清楚楚 qinng qīng chǔ chǔ 'crystal clear';

c. 干净 gān jìng 'clean’> 干干净净 gān gān jìng jìng 'perfectly clean';

d. 安静 ān jìng 'calm’> 安安静静 ān 'ān jìng jìng 'perfectly calm’;

e. 普通 pǔ tōng 'ordinary’> 普普通通 pǔ pǔ tōng tōng 'very ordinary'.

Examples (a) - (e) show that the reduplication of adjective AABB forms does not change word groups either. Because both 普通 pǔ tōng 'ordinary' and普普通通 pǔ pǔ tōng tōng 'very ordinary' are both categorized as adjectives in Mandarin, the test of word categorical membership cannot determine the reduplication process so the lexical decomposition test will be used. The lexical function of the AABB form reduplication has a semantic feature, that is [+ intensive] and is related to the meaning 'very'. Meanwhile, the meaning of 'very' does not function to form comparative sentences in Mandarin. Reduplication process has changed lexical meaning. 


\subsection{4. 'Iteratively': Verbal Lexeme + AABB Form}

Some verbs may be duplicated with the AABB form in Mandarin. The verb AB as the base word from the polysyllabic $\mathrm{AB}$ verb $>\mathrm{AABB}$ form is usually associated with 'iterative' [20].

a. 跌撞 dié zhuàng 'stagger'> 跌跌撞撞 dié die zhuàng zhuàng 'stagger on and on';

b. 拉扯 lā chě 'pull'> 拉拉扯扯 lā la chě chě 'pull over and over again';

c. 犹豫 yó u yù 'hesitate'> 犹犹豫豫 yó u you yù yù 'hesitate again and again';

d. 躲闪 duǒ shăn 'dodge’> 躲身朵闪闪 duǒ duo shăn shăn 'dodge again and again';

e. 指点 zhř diăn 'indicate'> 指指点点 zh ȟ zhi diăn diăn 'iteratively indicate'.

There is also no categorical change in the reduplicative proses because both the relevant base word and the reduplicative form are categorized as verbs. However, lexical meaning (iteratively) is changed by reduplication. So, it can say that the change in lexical meaning, and that is caused by reduplication of derivational.

\subsection{ABB Form}

\section{'Very': Adjective Lexeme + ABB Form}

Some adjective lexeme may be duplicated with AAB form in natural speech. Adjective generally relate to situations or the nature of circumstances, color, nature of a person, and sensing. The meaning of relevant base word will be highlighted by reduplication.
a. 黄蜡 Huáng là 'brassy’> 黄蜡蜡 huáng là là 'very brassy';
b. 暗沉 àn chén 'dark'> 暗沉沉 àn chén chén 'very dark';
c. 空旷 kōng kuàng 'empty’> 空旷旷 kōng kuàng kuàng 'very empty’;
d. 热乎 $r \grave{e} h \bar{u}$ 'hot / close together'> 热乎乎 $r e ̀ ~ h \bar{u} h \bar{u}$ 'very hot';
e. 水灵 shuí ling 'smart'> 水灵灵 shui ling líng 'very smart'.

Examples (a) - (e) show that the reduplication of adjective ABB forms does not change word groups either. Because both 黄蜡 Huáng là ‘brassy’ and黄蜡蜡 huáng là là 'very brassy’ are both categorized as adjectives in Mandarin. And we will see 'very' and highlight the conditions is created by reduplication. The lexical function of the AABB form reduplication has a semantic feature, that is [+ intensive] and is related to the meaning 'very'. Meanwhile, the meaning of 'very' does not function to form comparative sentences in Mandarin. The reduplication process is classified as derivational reduplication.

\subsection{ABAB Form}

Reduplication of the $\mathrm{ABAB}$ form repeats the polymorphic $\mathrm{AB}$ basis into the $\mathrm{ABAB}$ form $(\mathrm{AB}>\mathrm{ABAB})[21]$. Although these $\mathrm{ABAB}$ reduplications no longer seem to be creative.

\subsubsection{Meaning 'Very': Basic Adjectives + ABAB Form 'Very' and 'Intensive': Adjective Lexeme + ABAB Form}

Adjective $\mathrm{ABAB}$ form generally relate to situation or condition, color, size, distance, nature of people / animals, sensing, and feeling. For example, 金黄 jīn huáng 'golden' > 金黄金黄 jīn huáng jīn huáng 'very golden' while the 'color' is intensified by reduplicative form. Others will be shown in the following example (a-e).

a. 火红 huǒ hóng 'vermilion' > 火红火红 huǒ hóng huǒ hóng 'very vermilion';

b. 金黄 jīn huáng 'golden' > 金黄金黄 jīn huáng jīn huáng 'very golden';

c. 肥嫩 féi nèn 'tender' > 肥嫩肥嫩 féi nèn féi nèn 'pretty tender';

d. 鲜嫩 xiān nèn 'delicate’> 鲜嫩鲜嫩 xiān nèn xiān nèn 'pretty delicate';

e. 冰凉 bīng liáng 'cold'> 冰凉冰凉 bìng bīng liáng liáng 'very cold/freezing'.

Examples (a) - (e) show that the lexical meaning of 'very' and highlight the conditions and conditions involved. Meanwhile, the meaning of 'very' does not function to form comparative sentences in Mandarin. The reduplication process is classified as derivational reduplication.

\subsection{2. 'Iteratif' and 'Briefly': Verbal Lexeme + ABAB Forms}

According to Bianca \& Chiara, disyllabic bases (AB), the difference arises at the segmental level. In the diminishing function, the base is reduplicated as a whole (ABAB) [22]. The meaning that can be related to $\mathrm{ABAB}$ form reduplication such as 收拾收拾 shōu shi shōu shi is 'iterative' or 'briefly'. Others will show in examples (a-e).

a. 收拾 shōu shi 'tidy'> 收拾收拾 shōu shí shōu shi 'briefly tidy';

b. 忽闪 $h \bar{u}$ shăn 'flash' > 忽闪忽闪 $h \bar{u}$ shăn hū shăn 'briefly flash';

c. 扑闪 $p \bar{u}$ shăn 'blink'> 扑闪扑闪 $p \bar{u}$ shăn pū shăn 'briefly blink'; 
d. 扭搭niǔ $d \bar{a}$ 'twist' > 扭搭扭搭niǔ $d \bar{a}$ niǔ $d \bar{a}$ 'briefly twist';

e. 参观 cān guān 'berkunjung' > 参观参观 cān guān cān guān 'briefly visit'.

There is also no categorical change in the reduplicative proses because both the relevant base word and the reduplicative form are categorized as verbs. However, lexical meaning (iteratively) is changed by reduplication. So, it can say that the change in lexical meaning, and that is caused by reduplication of derivational.

\section{CONCLUSION}

Based on the data examined above, in addition to isolating meanings and figurative meanings. as we have shown with the reduplicative processes of Mandarin as we have shown with the reduplicative processes of Mandarin. This research has given all reduplication formation and meaning in Mandarin based on the distinction between derivation and inflection. It would has explained the meaning which is created by reduplicative process of $\mathrm{AA}$ form, $\mathrm{ABB}$ form, $\mathrm{AABB}$ form and $\mathrm{ABAB}$ form.

If the concept of lexeme arises empirically motivated in agglutinating languages whereby inflection markers modify the word form conveying relevant aspect in the syntactic contexts, its motivation is less grounded in isolating languages, where a very small number of words occur inflection markers, i.e. nominal reduplication AA星星xīng xīng 'stars', 框框 kuāng kuāng 'frames', and 杠杠 gàng gàng 'lines'.

Reduplication in Mandarin conveys values typically found in the inflectional domain. Many issues deserve a deeper analysis research can be disseminated in order to add teaching, learning, comparison, translation and reading material for future research.

\section{ACKNOWLEDGEMENTS}

I would like to thank my tutors and editorial team for their valuable guidance.

\section{REFERENCES}

[1] Harimurti Kridalaksana, Linguistic Dictionary (in bahasa), ed $4^{\text {th }}$, Jakarta: Gramedia Pustaka Utama, pp. 205, 2008.

[2] Carl Rubino, "Reduplication: Form, function and distribution." In Studies on Reduplication, Publisher: Mouton de Gruyter Berlin press, pp.11-32, 2005.

[3] Chiara Melloni and Bianca Basciano, "Reduplication across boundaries: The case of Mandarin," in The lexeme in descriptive and theoretical morphology, Publisher: Language Science Press, pp.325-363.

[4] Xíng hóngbīng, "Statistical analysis of Chinese words overlapping structure, language teaching and research (in Chinese)," Journal: Language Teaching and Linguistic Studies, pp. 32-37, 2000.

[5] Booij, Geert, "The demarcation of inflection: a synoptical survey," in Models of Inflection, Tübingen: Niemeyer, pp. 11-27, 1998.

[6] Frans Plank, "Inflection and derivation," The encyclopedia of languages and linguistics, Oxford: Pergamon Press, pp. 1671-1678, 1994.

[7] M.D.S Simatupang, "Morphemic reduplication in Indonesian (in Bahasa)," In Dissertation: Perpustakaan Universitas Indonesia, pp. 52-53, 1983.

[8] J.W.M. Verhaar, Introduction to linguistics (in Bahasa), Yogyakarta: Gadjah Mada University Press, pp.152-153, 1983

[9] Yuè Zhōngqí, "The grammatical nature and function of the noun AA overlap type Míng cí AA chóng dié shì de yŭ fã xìng zhì jí gōng néng (in Chinese)," Journal: Linguistic Researches, pp. 20-22, 2006.

[10] Wú yín, "On the AABB-style grammatical meaning of nouns and others (in Chinese)," Journal of Linguistic Researches, pp. 21-27, 2015.

[11] Wáng wěijìng, "On the conditions of verb overlap (in Chinese)," Modern Communication, pp. 83-84, 2018.

[12] Zhū Jungsōng, "The grammatical meaning of adjective overlapping (in Chinese)," Journal: Linguistics Study, vol. 3, pp.9-17, 2003.

[13] Dǒng Xuěsōng, "A comparative study of Chinese adjectives (in Chinese)," Journal: Modern Chinese, vol. 9, pp. 20-24, 2018

[14] Yao Jigang and Wang Zhe, "A Contrastive study on English and Chinese adverb," Journal of University of Shanghai for Science and Technology, vol. 37, no. 1, pp. 21-27, 2015.

[15] Susumu Ikeda, "Activation of the stativity in Chinese AABB type noun reduplication forms," Journal: Bulletin of Chinese Linguistics, pp. 289-300, 2015.

[16] Zhāng yìshēng, "AABB overlay of modern Chinese nouns (in Chinese)," Journal of Jiangsu Normal University, pp.58-62, 1999.

[17] Paris, Marie-Claude. "Un aperçu de la réduplication nominale et verbale en mandarin," Journal: Faits de langue vol. 29, pp. 65-76, 2007. 
[18] Booij, Geert. "Inflection and derivation," Morphologie/Morphology, Berlin: De Gruyter press, pp. 360-369, 2000.

[19] Shi Qin, "From combining to reduplication: On the diachronic changes of AABB reduplication patterns of Chinese adjectives," Studies in Language and Linguistics, vol. 2, pp. 99-105, 2007.

[20] Pān guóyīng, "Verb AABB overlapping grammar constitutes the source (in Chinese)," Journal of Huzhou University, pp. 73-78, 2018.

[21] Zhāng nà, "On the $\mathrm{ABAB}$ overlap of Chinese two-syllable adjectives (in Chinese)," Journal of Language and Literature, pp. 118-120, 2009.

[22] Giorgio Francesco Arcodia and Bianca Basciano, "Verbal reduplication in Sinitic," Proceedings of the Décembrettes 8th International, pp. 15-45, 2014.

\section{BIOGRAPHIES OF AUTHORS}

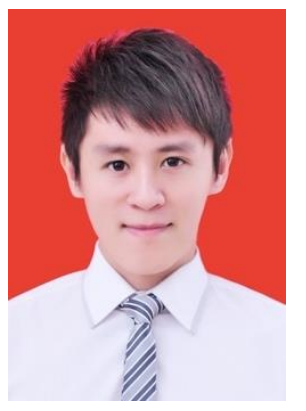

Shi Yu Xin is a Chinese student di Universitas Gadjah Mada.

2013.06, S-1 Guangxi University for Nationalities. Learning International Trade (3+1);

2013.09 - 2015.10, S-2 Department of linguistics, Gadjah Mada University;

2016.08 - Now, S-3 Department of Humaniora-linguistics, Gadjah Mada University.

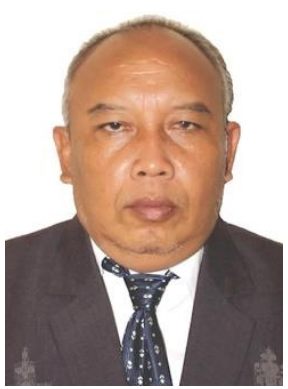

I Dewa Putu Wijana is a professor at Indonesian language, Gadjah Mada University.

1981: S-1 Faculty of Literature and Culture, Gadjah Mada University.

1987: S-2 Gadjah Mada University.

1995: S-3 Postgraduate Program Gadjah Mada University.

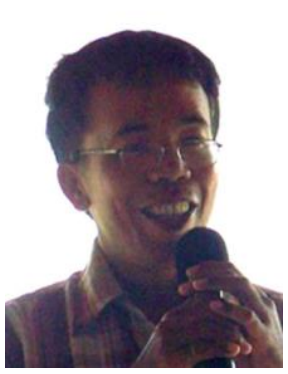

Yohanes Tri Mastoyo is a professor at Korean Language and Culture study program, Gadjah Mada University.

1985: S-1 Gadjah Mada University

1993: S-2 Gadjah Mada University

2015: S-3 Gadjah Mada University

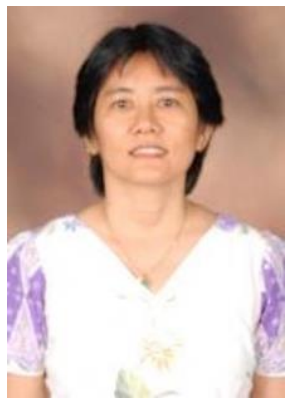

Hermina Sutami is a professor Mandarin language at Faculty of Cultural Sciences, Universitas Indonesia.

1975: S-1 Chinese history, Faculty of Cultural Sciences, Universitas Indonesia.

1992: S-2 Mandarin Linguistics, Universitas Indonesia dan Universitas Leiden.

1999: S-3 Mandarin Linguistics, Universitas Indonesia. 